\title{
New specimen of Psephoderma alpinum (Sauropterygia, Placodontia) from the Late Triassic of Schesaplana Mountain, Graubünden, Switzerland
}

\author{
James M. Neenan • Torsten M. Scheyer
}

Received: 22 October 2014/Accepted: 22 October 2014/Published online: 20 November 2014

(C) Swiss Geological Society 2014

\begin{abstract}
Psephoderma alpinum is an armoured, durophagous placodont known from the alpine Late Triassic. Here we present a new, well-preserved isolated skull discovered in the Alplihorn Member (Late Norian-Early Rhaetian) of the Kössen Formation, Schesaplana Mountain, which straddles the Swiss/Austrian border. Micro-computed tomographic $(\mu \mathrm{CT})$ scanning was used to create an accurate osteological reconstruction of the specimen, the first time this has been conducted for Psephoderma. We thus clarify disputed anatomical features from previous descriptions, such as a lack of a lacrimal and a pineal foramen that is enclosed by the parietal. We also present the first description based on $\mu \mathrm{CT}$ data of the lateral braincase wall, sphenoid region and some cranial nerve canals for Psephoderma, with the location of the hypophyseal seat, cerebral carotid foramina, dorsum sellae, prootic foramen, lacrimal foramen, as well as all dental foramina being described. This specimen represents the first skull of Psephoderma recovered in Switzerland, and features such as poorly-sutured braincase elements and its relatively small size compared to other known specimens may indicate that it was a sub-adult.
\end{abstract}

Keywords Psephoderma Placodontia $\cdot$ Late triassic . Skull $\cdot \mu \mathrm{CT}$ scanning $\cdot$ Braincase

Editorial handling: D. Marty.

Electronic supplementary material The online version of this article (doi:10.1007/s00015-014-0173-9) contains supplementary material, which is available to authorized users.

J. M. Neenan $(\bowtie) \cdot$ T. M. Scheyer

Palaeontological Institute and Museum, University of Zurich,

Karl Schmid-Strasse 4, 8006 Zurich, Switzerland

e-mail: james.m.neenan@gmail.com

\begin{abstract}
Abbreviations
IVPP Institute of Vertebrate Paleontology and Paleoanthropology, China

MB.R. Museum für Naturkunde der Humboldt Universität, Berlin, Germany

MSNM Museo Civico di Storia Naturale di Milano, Italy

PIMUZ Palaeontological Institute and Museum, University of Zurich, Switzerland
\end{abstract}

\section{Introduction}

Psephoderma alpinum Meyer 1858 is a highly-nested, armoured placodont best known from the Norian and Rhaetian (Late Triassic) of the Alps (e.g., Rieppel 2000, 2001). Being a cyamodontoid placodont, Psephoderma exhibited a characteristic crushing dentition and was heavily armoured, with a large dorsal shield and smaller pelvic shield (e.g., Pinna and Nosotti 1989; Renesto and Tintori 1995). Unlike most other placodonts, however, Psephoderma is characterised by a very narrow, elongate and edentulous rostrum, presumably used for probing soft sediments for prey items, much like recent batoid rays and skates (e.g., Mazin and Pinna 1993; Rieppel 2002a). It is one of the best understood placodonts, with both the cranial and postcranial osteology having been thoroughly described by Pinna (e.g., 1976, 1980), Pinna and Nosotti (1989) and Rieppel (2001), with further studies on its armour carried out by Westphal (1976), Rieppel (2002b) and Scheyer (2007), its palaeoecology by Mazin and Pinna (1993) and Renesto and Tintori (1995), its phylogenetic position by Rieppel (2000, 2001) and Neenan et al. (2013), and its tooth replacement by Neenan et al. (2014). Here we present and describe a new specimen of Psephoderma 
alpinum from Schesaplana Mountain, the first skull of this taxon reported from Switzerland (Fig. 1).

At $2964 \mathrm{~m}$, Schesaplana Mountain is the highest peak in the Rätikon mountain range, and is situated at the western edge of the Northern Calcareous Alps, on the border between Graubünden (Grisons), Switzerland, and Vorarlberg, Austria. Besides being a classical area of alpinism and tourism, the geological character of that region, especially its structural and tectonic setting, has been studied extensively (e.g., Reithofer et al. 1964; Tollmann 1976, 1985; Plöchinger 1980; Trümpy 1980; Laubscher 1989; Furrer et al. 1992; Oberhauser 1998; Trümpy and Oberhauser 1999). The most fossiliferous layers at Schesaplana belong to the Kössen Formation, a sequence of siliciclastic sediments of late Norian to early Rhaetian age, directly overlying the 'Hauptdolomit' Formation (Norian). As early as the middle of the 19th century, many invertebrates from sediments of the
Fig. 1 The skull of Psephoderma alpinum PIMUZ A/III 1491. Photographs of the specimen in dorsal (a) and palatal (b) views. Virtual reconstructions based on $\mu \mathrm{CT}$ data in dorsal (c) and palatal (d) views. Scale bar $20 \mathrm{~mm}$
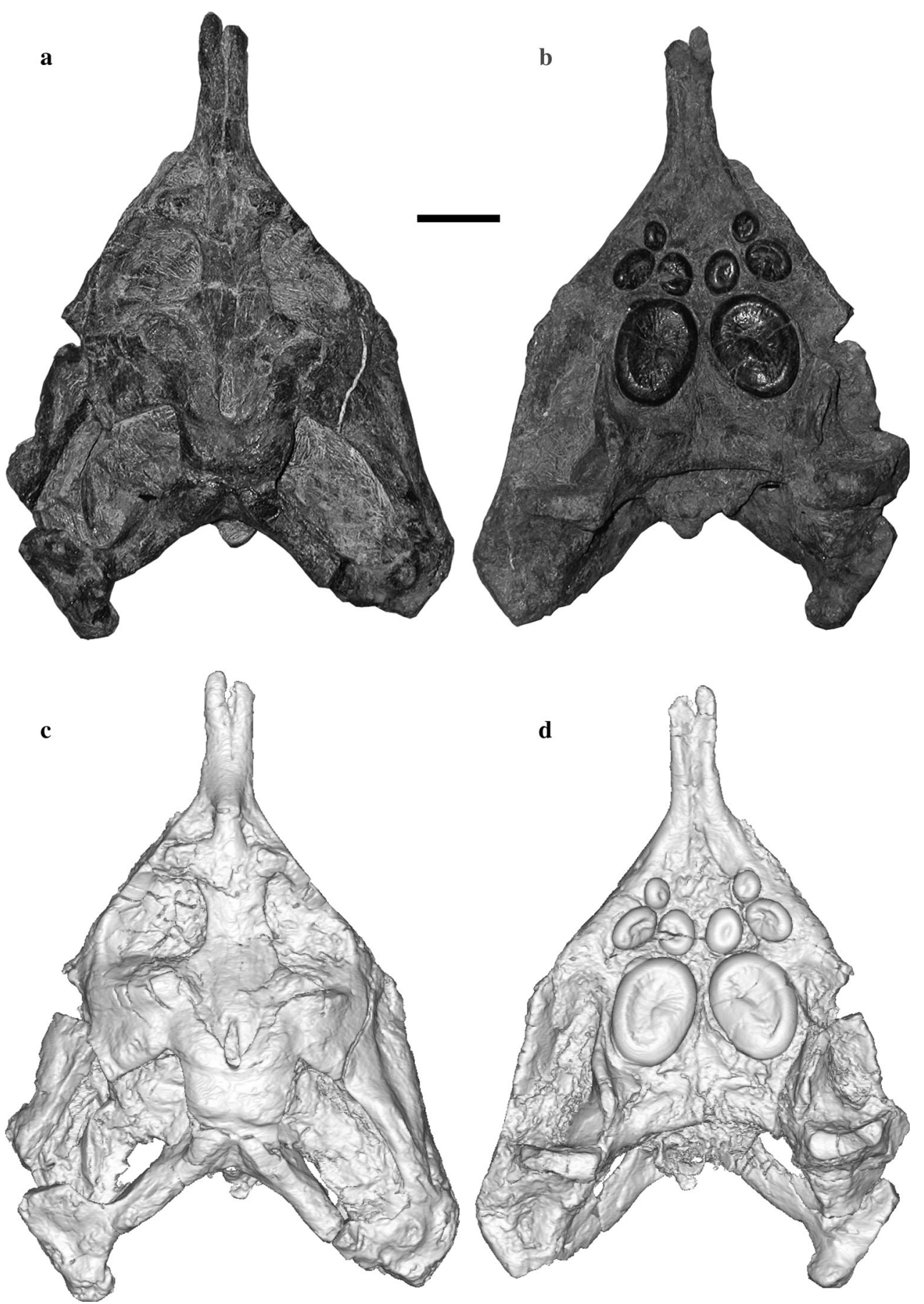
"Kössener Schichten" (Suess 1852), now known as the Kössen Formation (e.g., Furrer 1993; Feist-Burkhardt et al. 2008) were described from the Schesaplana locality (e.g., Escher von der Linth 1854; Theobald 1861). On the other hand, it was only with the beginning of the 20th century that the first vertebrate fossils were described from the locality (e.g., Broili 1920), with abundant material assigned to sharks, osteichthyans, ichthyosaurs, pterosaurs and placodonts, mostly in the form of disarticulated teeth, bones and scales (Furrer et al. 1992; Furrer 1993; Fröbisch and Fröbisch 2006).

\section{Materials and methods}

\subsection{Geological setting}

Furrer (1993) subdivided the Kössen Formation into several members, including the Alplihorn Member for the lowermost part of the formation, followed by the Schesaplana Member (including massive, banked or lentil-shaped coral reef carbonate (breccia) complexes, the informally named "Zirmenkopf-Kalke") for which the western flank of the Schesaplana is the type profile (figure 6, Furrer 1993), and the Ramoz- and Mitgel Members to the top. In this sequence, the bivalve-rich dark shales, marls and carbonates with the intercalated siltstones and dolomites of the Alplihorn Member yield the majority of the vertebrate fossils (Furrer 1993; TMS pers. obs.).

Because of the complex tectonic history including several deformation phases of the Lechtal nappe, the layers of the Schesaplana Member dip sub-vertically at the summit of Schesaplana as part of a large anticline, thus the older Alplihorn Member extends over the plateau on the slope south of the summit on the Swiss side of the border (Furrer 1993; Froitzheim et al. 2012). These tectonic conditions together with the alpine setting thus far precluded systematic fossil excavations in this area, so the findings are based on surface collections and thus can only be assigned to Late Norian-Early Rhaetian in age.

An almost complete skull of the placodont Psephoderma alpinum was found by TMS during a diploma mapping course led by Prof. N. Froitzheim (Steinmann-Institute for Geology, Mineralogy and Palaeontology, University of Bonn, Germany), and has subsequently been prepared in several steps with pneumatic tools and needles, as well as with formic acid $\left(\mathrm{CH}_{2} \mathrm{O}_{2}\right)$. Coordinates of the find in the field within the Alplihorn Member are $47^{\circ} 03^{\prime} 07^{\prime \prime} \mathrm{N}$ and $9^{\circ} 42^{\prime} 04^{\prime \prime} \mathrm{E}$.

\subsection{Specimen}

The new specimen, PIMUZ A/III 1491, is an almost complete skull that lacks a lower jaw and has been somewhat dorsoventrally crushed, especially in the orbital and preorbital regions (Fig. 1). It was $\mu \mathrm{CT}$ scanned at the Steinmann Institute for Geology, Mineralogy and Palaeontology, University of Bonn with a Phoenix $\mathrm{v}$ tome $\mathrm{x} \mathrm{s}$, using a voltage of $130 \mathrm{kV}$ and a current of $130 \mu \mathrm{A}$, resulting in a slice thickness of $0.166 \mathrm{~mm}$. $\mu \mathrm{CT}$ slice data were then visualised with Avizo 6.2 and Mimics 16.0 (see interactive 3D PDF, Online Resource 1).

\section{Systematic palaeontology}

Sauropterygia Owen 1860

Placodontiformes Neenan et al. 2013

Placodontia Cope 1871

Cyamodontoidea Nopcsa 1923

Placochelyidae Romer 1956

Psephoderma Meyer 1858a

$P$. alpinum Meyer $1858 \mathrm{~b}$

\section{Description}

On first inspection, the new specimen is very similar to the isolated skull MSNM V471 from Monte Cornizzolo, which has been described in detail (Pinna 1976, 1980; Pinna and Nosotti 1989), most recently by Rieppel (2001). Like this specimen, PIMUZ A/III 1491 is also dorsoventrally crushed, particularly in the preorbital region, is missing the posterior-most part of one of the squamosals (the left in the former and right in the latter) and, at $146.5 \mathrm{~mm}$ in total length, is of a similar size (for a full list of measurements, please refer to Online Resource 2 ). However, the occipital region of the skull is badly damaged, with the basioccipital, exoccipitals, and most of the opisthotics being missing and the supraoccipital being broken. PIMUZ A/III 1491 can be identified as Psephoderma alpinum owing to the presence of a very narrow, elongate and edentulous rostrum; that extend far posterior to the external nares, separating the reduced nasals; relatively narrow upper temporal fenestrae; pineal foramen located anterior to a distinct step in the skull roof; small postfrontals; two 'bean shaped' maxillary tooth plates; two 'bean shaped' palatine tooth plates, the anterior one being similar in size to the maxillary teeth and the posterior one being larger and distinctly elongate.

There are some distinct differences between PIMUZ A/III 1491 and MSNM V471, as described by Rieppel (2001) (Fig. 2). The frontals do not enter the anterior margin of the pineal foramen, the latter being fully enclosed by the parietal. We thus corroborate the reconstructions of Pinna (1976) and Pinna and Nosotti (1989) in this regard, who also indicated that the frontals do not 


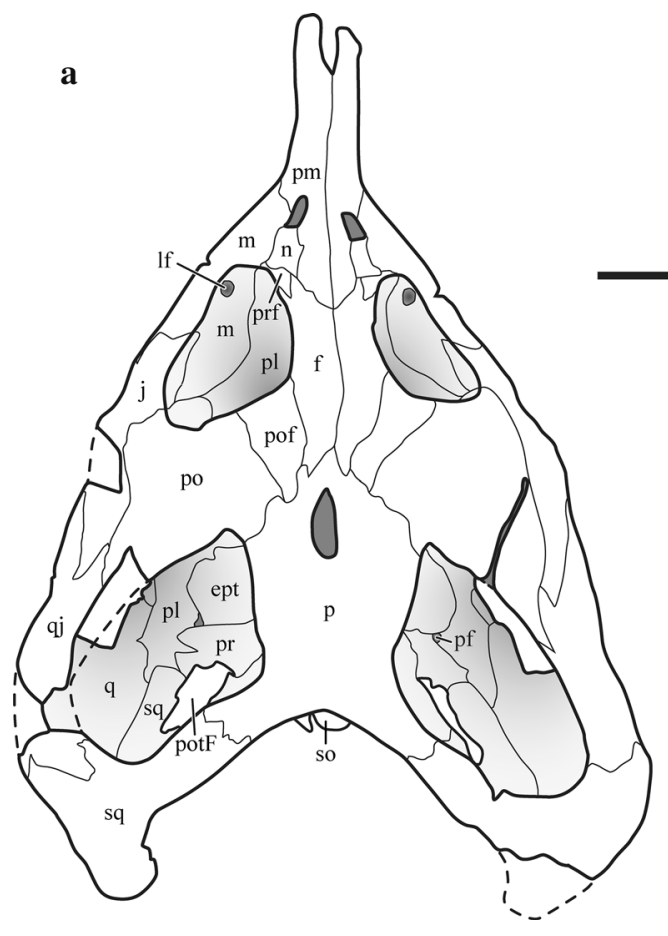

Fig. 2 Reconstructions of PIMUZ A/III 1491 in dorsal (a) and palatal (b) views based on $\mu \mathrm{CT}$ data and observations of outward appearance. Dashed lines indicate predicted outline due to breakage. Scale bar $20 \mathrm{~mm}$. alf labial foramen of anterior cutaneous branch of superior alveolar nerve, $d f$ dental foramen, ept epipterygoid, $f$ frontal, $j$ jugal, $l f$ lacrimal foramen, $m$ maxilla, $n$ nasal, $p$ parietal, $p f$ prootic foramen, $p l$

reach the pineal foramen-although it is important to note that intraspecific variation of this feature cannot be ruled out. In contrast to the latter authors' interpretation, however, the anterior border of the parietal in PIMUZ A/III 1491 is roughly triangular (as is shown for MSNM V471 by Rieppel 2001), with its anterior-most tip entering between the two posterior short processes of the paired frontals. However, contra to Pinna (1976) and Pinna and Nosotti (1989), there is no indication of a lacrimal (as is the case with all other placodonts).

PIMUZ A/III 1491 further provides insights into cranial anatomy that were previously unknown or unclear in Psephoderma alpinum. The exact shape of the nasals can be seen, showing that they in fact contact a narrow lateral anterior process of the frontals (Fig. 2). Indeed, the prefrontal can be reconstructed as a small element, similar in size to the nasal. The maxilla forms the anterior half of the ventral orbital margin and contributes a relatively large amount to the suborbital region. The maxilla also houses a large lacrimal foramen (note that despite the lack of a lacrimal, this foramen is still referred to as such) near the anterior margin of the orbit, as well as two foramina for the cutaneous branches of the superior alveolar nerve (Nosotti and Pinna 1996) on its lateral margin, on approximately

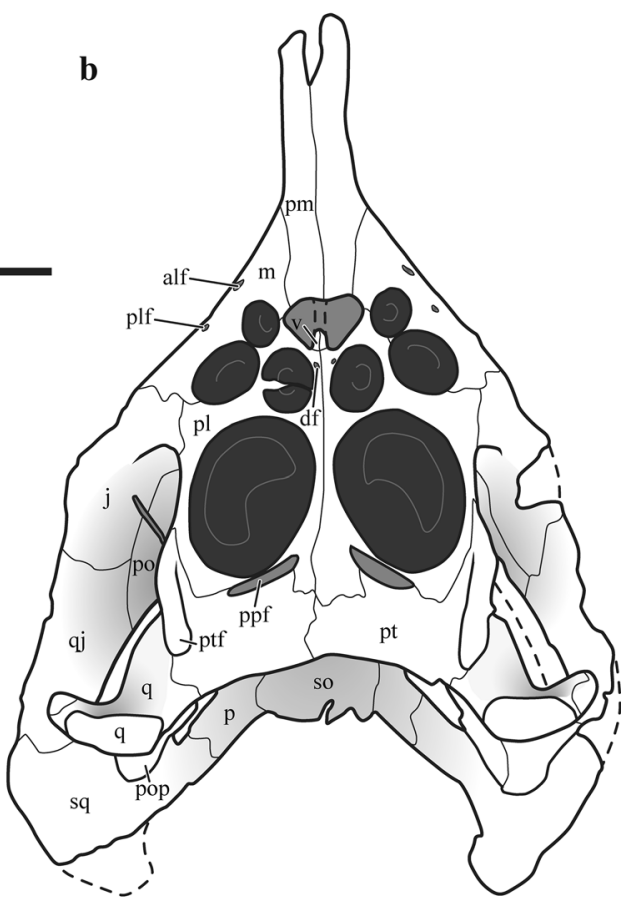

palatine, plf labial foramen of posterior cutaneous branch of superior alveolar nerve, pm premaxilla, po postorbital, pof postfrontal, pop paroccipital process of the opisthotic, $p o t F$ post-temporal fenestra, $p p f$ pterygo-palatine foramen, $p r$ prootic, $p r f$ prefrontal, $p t$ pterygoid, $p t f$ pterygoid flange, $q$ quadrate, $q j$ quadratojugal, so supraoccipital, $s q$ squamosal, $v$ vomer

either side of the anterior tooth plate. These foramina lead directly into the alveolar spaces above each maxillary tooth plate (Fig. 3), providing not only innervation, but a blood supply for the functional and developing replacement teeth (see Neenan et al. 2014 for a summary). The palatine is a large element that contains two tooth plates, the posterior of which is elongated. Medial to the anterior tooth plate is a small dental foramen (possibly for a medial branch of an alveolar nerve), and posterior to the posterior tooth plate sits a large pterygo-palatine foramen ("posterior dental lamina foramen' sensu Rieppel 2001). The jugal clearly enters the ventral margin of the orbit and extends far posteriorly in a tapering process until approximately the first third of the upper temporal fenestra. The postfrontal is a small, narrow element that meets the parietal. Conversely, the postorbital is a very large element, and forms a large portion of the posterior margin of the orbit. It extends posteriorly in a tapering process to form approximately half of the anterior lateral margin of the upper temporal fenestra. The parietal is fused, forms the medial margins of the upper temporal fenestrae, and features descending processes that meet the post-temporal fenestra, as well as the dorsal margins of the prootic and epipterygoid. The pterygoid has a typically reduced palatal exposure, even 

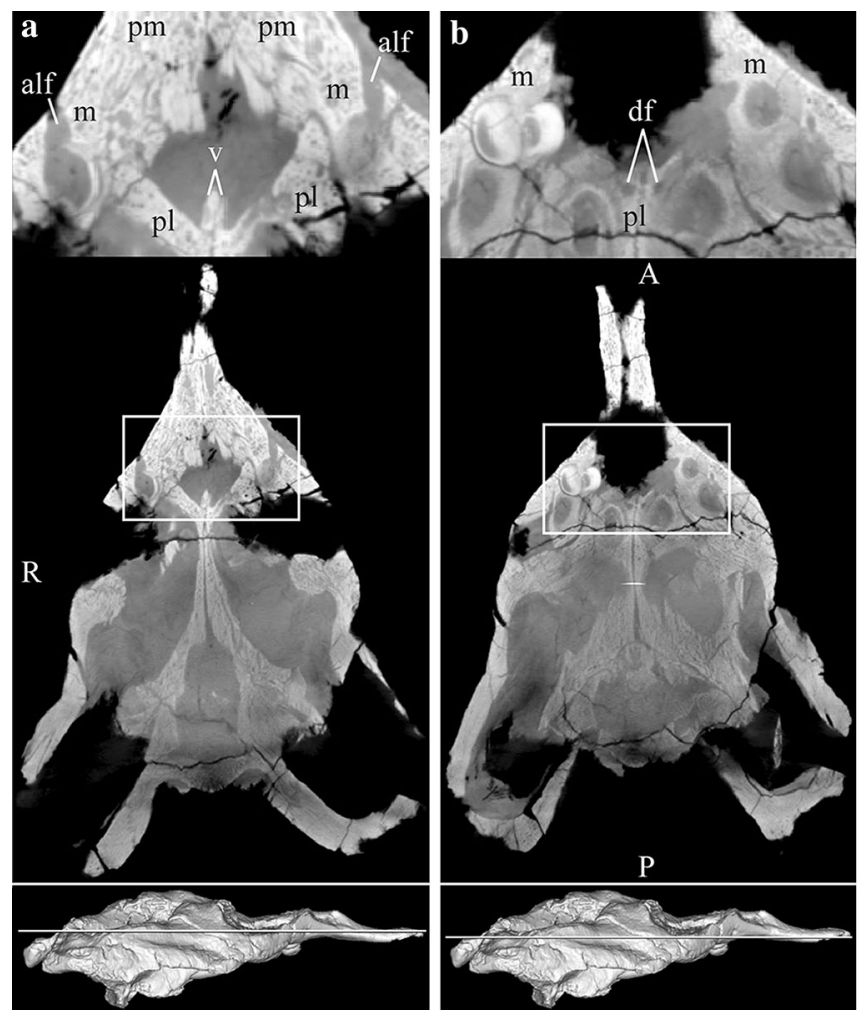

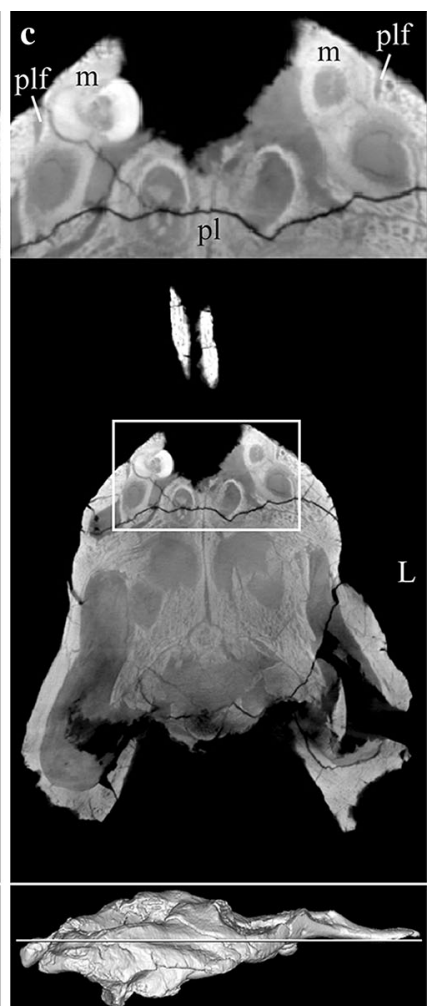

Fig. 3 Axial slices through PIMUZ A/III 1491 showing dental nerve canals (above) and their position in the skull (below). a Canals for the anterior cutaneous branch of the superior alveolar nerve. b Canals for the medial dental foramen, possibly for a medial branch of the superior alveolar nerve. $\mathbf{c}$ Canals for the posterior cutaneous branch of the superior alveolar nerve. Not to scale. Abbreviations as in Fig. 2 plus, $A$ anterior, $L$ left, $P$ posterior, $R$ right

both). The sphenoid region has also been revealed, showing a small parabasisphenoid complex with an anterior process that forms the hypophyseal seat, a pair of cerebral carotid formina and a dorsum sellae (Fig. 5). This complex sits medial to the epipterygoids, with the raised, ' $\mathrm{v}$-shaped' palatine suture directly anterior to it. As well as the braincase, the internal nares can be seen clearly, with the premaxillae entering the anterior margin. In addition, the narrow, paired and medially-situated vomers can be seen, and are broken, with only a small posterior portion remaining.

\section{Discussion}

We present the first description of a cyamodontoid braincase and sphenoid region described with the use of microcomputed tomographic $(\mu \mathrm{CT})$ scanning. The anterior process of the parabasispehenoid is very similar to that of the closely-related Placochelys placodonta (paratype, MB.R.1765; Rieppel 2001; JMN pers. obs.) in that it has a small dorsal surface containing the paired and very small cerebral carotid foramina (the probable position of the hypophyseal seat), and a dorsum sellae. This shares several 
Fig. 4 Coronal slices through PIMUZ A/III 1491 showing the left (a) and right (b) prootic foramina and surrounding elements. Abbreviations as in Figs. 2 and 3 plus, $D$ dorsal, $p b s$ parabasisphenoid, $V$ ventral
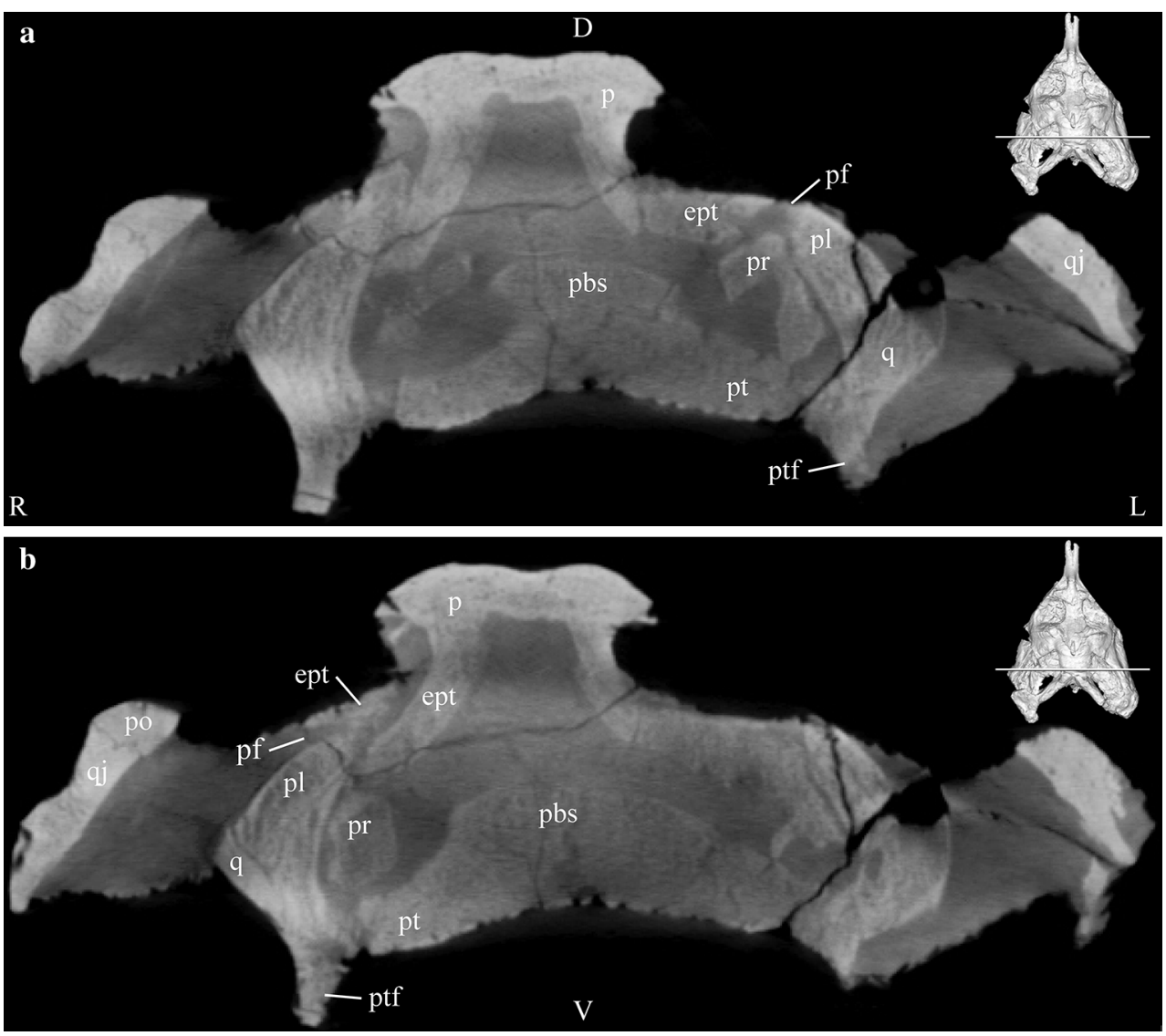

similarities with the more basal placodontoid, Placodus gigas, although these structures are relatively larger than in either Psephoderma or Placochelys (Neenan and Scheyer 2012). We have also been able to reconstruct the lateral braincase wall and locate the prootic foramen. The latter is situated in similar position to that of Cyamodus $\mathrm{ku}$ hnschnyderi (Nosotti and Pinna 1996) and appears to be consistent for all cyamodont placodonts. In Placodus gigas, where the epipterygoid is not incorporated into the braincase wall, the prootic foramen is fully enclosed by the prootic itself (Neenan and Scheyer 2012). We were also able to identify, for the first time, the anterior and posterior labial foramina of the cutaneous branches of the superior alveolar nerve (terminal branches of the maxillary portion of the trigeminal nerve), as well as a pair of small dental foramina medial to the anterior palatine tooth plates. These, in combination with the large pterygo-palatine foramina, would have housed all the nerve canals and blood vessels necessary to innervate and sustain all of the functional tooth plates and the developing replacement teeth.

While it has been suggested that the elongate rostrum of Psephoderma was used to probe soft sediments for prey items (see above), one might expect to see a network of nerve canals within it, as is the case with the similar Chinese placodont, Glyphoderma kangi (JMN pers. obs.), or even the non-placodont eosauropterygian, Pliosaurus kevani (Foffa et al. 2014). However, this is not the case in PIMUZ A/III 1491, indicating that the rostrum may not have been as sensitive as previously hypothesised. On the other hand, given the degree of crushing in the rostrum as well as the preservational setting of the locality, this may simply be taphonomic in origin.

The poor preservational state of the occipital region (i.e., the broken/missing occipital bones and opisthotics) is strikingly similar to that of the other well-preserved skull specimen of Psephoderma alpinum, MSNM V471, that was described in some detail by Pinna (1980), Nosotti and Pinna (1993) and Rieppel (2001). Indeed, this is also similar to another closely-related placochelyid placodont from China, Psephochelys polyosteoderma (IVPP V 12442; JMN pers. obs.), which is also missing these elements as well as the prootics. This could be interpreted as the specimens being at an early ontogenetic stage, as bones do not become fully fused/sutured until adulthood, often becoming disarticulated and lost during fossilisation. This is corroborated by the relatively small sizes of the skulls compared to those of other Psephoderma specimens. The almost complete specimens ST82003 (stored at the Museo della Vicaria di S. Lorenzo a Zogno, Bergamo, Italy) and MSNM V527 measure 155 and $125 \mathrm{~mm}$, respectively, from the tip of the snout 

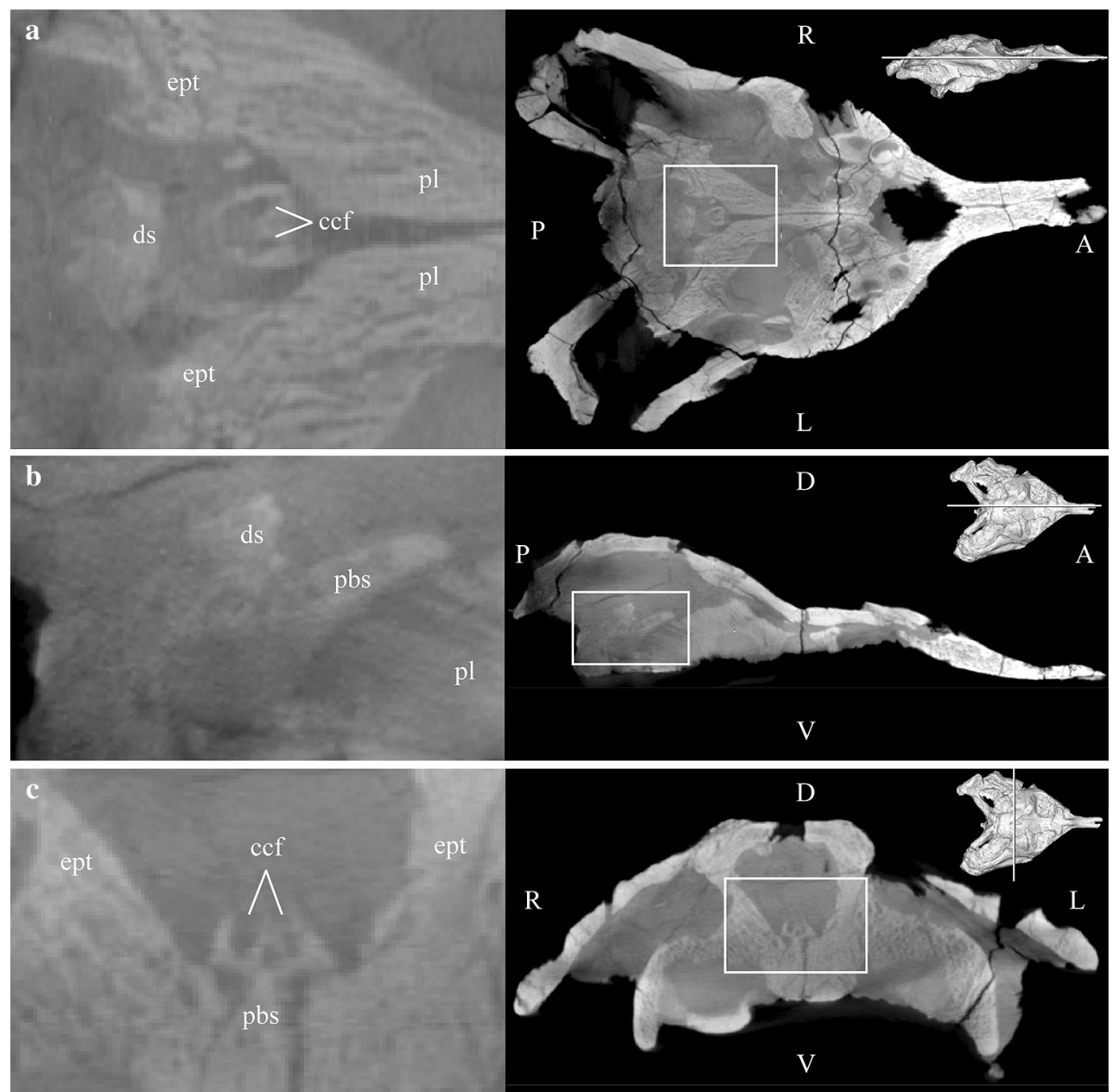

Fig. 5 Slices through PIMUZ A/III 1491 showing different views of the sphenoid region (left) and their position in the skull (right). a Axial slice showing the dorsal surface of the anterior process, with cerebral carotid foramina and dorsum sellae shown. b Sagittal slice

until the occipital condyle (Renesto and Tintori 1995). However, PIMUZ A/III 1491 has a snout to supraoccipital length of $121.9 \mathrm{~mm}$ (the occipital condyle is not preserved) and MSNM V471 has a total skull length of only $119.5 \mathrm{~mm}$ (Pinna and Nosotti 1989). Another explanation of this condition could be a functional one. It has been previously suggested that while placochelyid placodonts were most likely durophagous, they may have been specialised for eating less hard prey than other placodonts, such as the crustaceans that were abundant in concurring sediments (Stefani et al. 1991; Renesto and Tintori 1995). A robust, well-sutured braincase is most likely an adaptation for durophagy (Neenan and Scheyer 2012), so a diet of less hard food would not necessitate such a highly robust braincase, particularly in the posterior of the skull, and could account for the less well-sutured elements present in Psephoderma specimens. This could thus be interpreted as further showing the parabasisphenoid and dorsum sellae in lateral view. c Coronal slice showing the parabasisphenoid in a medial position to the epipterygoids. Not to scale. Abbreviations as in Figs. 2, 3 and 4 plus, $c c f$ cerebral carotid foramina, $d s$ dorsum sellae

evidence that placochelyids such as Psephoderma and Psephochelys did indeed consume softer prey.

\section{Conclusions}

This paper has presented an important new skull specimen of Psephoderma alpinum, the first described from Switzerland. While much of its outward osteology is similar to that of previous descriptions, PIMUZ A/III 1491 enabled us to clarify the location of several bone sutures and determine that there may be a degree of intraspecific variation between Psephoderma specimens. We were also able to reconstruct the lateral braincase wall, and describe the sphenoid region and several cranial nerve foramina. This work is therefore significant for future phylogenetic and comparative studies. 
Scanning of the similar specimen MSNM V471 may still reveal more information, such as confirming the observation of Rieppel (2001) that the frontals enter the anterior margin of the pineal foramen, the presence (or lack thereof) of rostral sensory nerve canals and the morphology of the endosseous labyrinth.

Acknowledgments We are grateful to Heinz Furrer (PIMUZ) for providing advice and expertise on the locality, as well as access to the specimen. Thanks also go to Nicole Klein (SMNS, Stuttgart) for CT scanning, Niko Froitzheim and Thorsten Nagel (Bonn) for their help and advice in the field, as well as Nadine Machalek (St. Augustin), and Nadia and Jörg Fröbisch (Berlin) for their efforts in recovering fossils from Schesaplana. Olaf Dülfer (Bonn) and Sebastian Egberts (Philadelphia) are thanked for the initial preparation of the specimen, as are Esther Bärtschi, Christian Mitgutsch, Laura Wilson, Ingmar Werneburg (former and/or current members of the PIMUZ), and Marcelo Sánchez (PIMUZ) for various aid and discussion. Rosi Roth (PIMUZ) is thanked for advice in taking photographs, as is Marie Attard (UNE, Australia) for aid in constructing the supplemental pdf. We would also like to thank Stefania Nosotti and an anonymous reviewer for their comments which helped improve the manuscript, as well as Daniel Marty for editorial advice. The Swiss National Science Foundation is acknowledged for funding the project (grant no. 31003A 146440 to TMS).

\section{References}

Broili, F. (1920). Ein neuer Placodontier aus dem Rhaet der bayerischen Alpen. Sitzungsberichte der Bayerischen Akademie der Wissenschaften. Mathematisch-physikalische Klasse, 1920, 311-322.

Cope, E. D. (1871). The systematic arrangement of the Reptilia. Proceedings of the American Association for the Advancement of Science, 19, 226-247.

Escher von der Linth, A. (1854). B. Briefliche Mitteilungen. 2. Herr Escher von der Linth and Herrn Weiss. Zeitschrift der Deutschen geologischen Gesellschaft, 6(3), 519-521.

Feist-Burkhardt, S., Götz, A. E., Szulc, J., Aigner, T., Borkhataria, R., Geluk, M., et al. (2008). Triassic. In T. McCann (Ed.), The geology of central Europe (pp. 749-821). London: The Geological Society.

Foffa, D., Sassoon, J., Cuff, A. R., Mavrogordato, M. N., \& Benton, M. J. (2014). Complex rostral neurovascular system in a giant pliosaur. Naturwissenschaften, 101, 453-456.

Fröbisch, N. B., \& Fröbisch, J. (2006). A new basal pterosaur genus from the Upper Triassic of the Northern Calcareous Alps of Switzerland. Palaeontology, 49, 1081-1090.

Froitzheim, N., Weber, S., Nagel, T. J., Ibele, T., \& Furrer, H. (2012). Late Cretaceous extension overprinting a steep belt in the Northern Calcareous Alps (Schesaplana, Rätikon, Switzerland and Austria). International Journal of Earth Sciences, 101, $1315-1329$.

Furrer, H. (1993). Stratigraphie und Facies der Trias/JuraGrenzschichten in den oberostalpinen Decken Graubündens. Ph.D. dissertation (pp. 99). Zurich: University of Zurich.

Furrer, H., Eichenberger, U., Froitzheim, N., \& Wurster, D. (1992). Geologie, Stratigraphie und Fossilien der Ducankette und des Landwassergebiets (Silvretta-Decke, Ostalpin). Eclogae Geologicae Helvetiae, 85, 245-256.
Laubscher, H. P. (1989). The tectonics of the Southern Alps and the Austro-Alpine nappes: a comparison. In M. P. Coward, D. Dietrich, \& R. G. Park (Eds.), Geological Society, London, Special Publications, No. 45 (pp. 229-241). Oxford: Blackwell.

Mazin, J.-M., \& Pinna, G. (1993). Palaeoecology of the armoured placodonts. Paleontologia Lombarda N. S., 2, 83-91.

Meyer, H. V. (1858a). Psephoderma Alpinum aus dem der Alpen. Neues Jahrbuch für Mineralogie, Geognosie, Geologie und Petrefaktenkunde, 1858, 646-650.

Meyer, H. V. (1858b). Psephoderma Alpinum aus dem der Alpen. Palaeontographica, 6, 246-252.

Neenan, J. M., Klein, N., \& Scheyer, T. M. (2013). European origin of placodont marine reptiles and the evolution of crushing dentition in Placodontia. Nature Communications, 4, 1621. doi:10.1038/ ncomms2633.

Neenan, J. M., Li, C., Rieppel, O., Bernardini, F., Tuniz, C., Muscio, G., et al. (2014). Unique method of tooth replacement in durophagous placodont marine reptiles, with new data on the dentition of Chinese taxa. Journal of Anatomy, 224, 603-613.

Neenan, J. M., \& Scheyer, T. M. (2012). The braincase and inner ear of Placodus gigas (Sauropterygia, Placodontia) - a new reconstruction based on micro-computed tomographic data. Journal of Vertebrate Paleontology, 32(6), 1350-1357.

Nopcsa, F. (1923). Die Familien der Reptilien. In W. Soergel (Ed.), Fortschritte der Geologie und Palaeontologie (Vol. 2, pp. 1-210). Berlin: Borntraeger.

Nosotti, S. \& Pinna, G. (1993). New data on placodont skull anatomy. Paleontologia Lombarda n.s. della Società Italiana di Scienze Naturale e del Museo Civico di Storia Naturale di Milano, 2, 109-114.

Nosotti, S., \& Pinna, G. (1996). Osteology of the skull of Cyamodus kuhnschnyderi Nosotti \& Pinna 1993 (Reptilia, Placodontia). Paleontologia Lombarda, 6, 1-42.

Oberhauser, R. (1998). Erläuterungen zur Geologisch-Tektonischen Übersichtskarte von Vorarlberg 1:200000 (pp. 42). Vienna: Geologische Bundesanstalt.

Owen, R. (1860). Palaeontology; or, a systematic summary of extinct animals and their geologic remains. Edinburgh: Adam and Charles Black.

Pinna, G. (1976). Osteologia del cranio del rettile placodonte Placochelyanus stoppanii (Osswald 1930) basata su un nuovo esemplare del Retico Lombardo. Atti della Società Italiana di Scienze Naturali e del Museo Civico di Storia Naturale di Milano, 117, 3-45.

Pinna, G. (1980). Psephoderma alpinum Meyer, 1858: rettile placodonte del Retico europeo. In Volume Sergio Venzo. Università di Parma (149-157).

Pinna, G., \& Nosotti, S. (1989). Anatomia, morfologia funzionale e paleoecologia del rettile placodonte Psephoderma alpinum Meyer, 1858. Memoire della Società Italiana di Scienze Naturali e del Museo Civico di Storia Naturale di Milano, 25, 17-50.

Plöchinger, B. (1980). Die Nördlichen Kalkalpen. In R. Oberhauser (Ed.), Der Geologische Aufbau Österreichs (pp. 217-264). Vienna: Springer.

Reithofer, O., Schmidegg, O., \& Oberhauser, R. (1964). Exkursion III/1: Rätikon. Mitteilungen der Geologischen Gesellschaft in Wien, 57, 225-242.

Renesto, S., \& Tintori, A. (1995). Functional morphology and mode of life of the Late Triassic placodont Psephoderma alpinum Meyer from the Calcare di Zorzino (Lombardy, N Italy). Rivista Italiana di Paleontologia e Stratigrafia, 101(1), 37-48.

Rieppel, O. (2000). Sauropterygia I-Placodontia, Pachypleurosauria, Nothosauroidea, Pistosauroidea. In P. Wellnhofer (Ed.), Encyclopedia of Paleoherpetology (p. 134). Munich: Verlag Dr. Friedrich Pfeil. 
Rieppel, O. (2001). The cranial anatomy of Placochelys placodonta Jaekel, 1902, and a review of the Cyamodontoidea (Reptilia, Placodonta). Fieldiana: Geology, New Series, 45, 1-104.

Rieppel, O. (2002a). Feeding mechanics in Triassic stem-group sauropterygians: the anatomy of a successful invasion of Mesozoic seas. Zoological Journal of the Linnean Society, $135,33-63$.

Rieppel, O. (2002b). The dermal armor of the cyamodontoid placodonts (Reptilia, Sauropterygia): morphology and systematic value. Fieldiana: Geology, New Series, 46, 1-41.

Romer, A. S. (1956). The osteology of the reptiles (p. 772). Chicago: The University of Chicago Press.

Scheyer, T. M. (2007). Skeletal histology of the dermal armor of Placodontia: the occurrence of 'postcranial fibro-cartilaginous bone' and its developmental implications. Journal of Anatomy, 211, 737-753.

Stefani, M., Arduini, P., Garassino, A., Pinna, G., Teruzzi, G., \& Trombetta, G. L. (1991). Palaeoenvironment of extraordinary fossil biotas from the Upper Triassic of Italy. Atti della Società Italiana di Scienze Naturali e del Museo Civico di Storia Naturale di Milano, 132(24), 309-335.
Suess, E. (1852). Untersuchungen der Brachiopoden in den sogen. Kalkschichten von Kössen. Jahrbuch der Kaiserlich-Königlichen Geologischen Reichsanstalt, 3, 180-181.

Theobald, G. (1861). Geognostische Uebersicht des Prätigau's. Jahresbericht der Naturforschenden Gesellschaft Graubündens. Neue Folge. VI. Jahrgang (Vereinsjahr 1859-1860), 5-41.

Tollmann, A. (1976). Der Bau der Nördlichen Kalkalpen. Orogene Stellung und regionale Tektonik. Monographie der Nördlichen Kalkalpen (Teil 3) (p. 449). Vienna: Franz Deuticke.

Tollmann, A. (1985). Geologie von Österreich, Bd. 2: Ausserzentralalpiner Anteil (p. 710). Vienna: Franz Deuticke.

Trümpy, R. (1980). Geology of Switzerland: a guide book. Part A. An outline of the Geology of Switzerland (p. 104). Basel: Wepf \& Co.

Trümpy, R., \& Oberhauser, R. (1999). Zu den Beziehungen zwischen österreichischen und schweizerischen Geologen: die Tektonik der Alpen, 1875-1950. Abhandlungen der Geologischen Bundesanstalt in Wien, 56, 13-28.

Westphal, F. (1976). The dermal armour of some Triassic placodont reptiles. In A. D. A. Bellairs \& C. B. Cox (Eds.), Morphology and Biology of Reptiles (pp. 31-41). London: Academic Press. 